\title{
PERAN AMDAL DALAM MENGAWAL ETIKA BISNIS TERHADAP LINGKUNGAN DALAM PERSPEKTIF EKONOMI SYARIAH
}

\author{
Devid Frastiawan Amir Sup \\ Universitas Darussalam Gontor \\ devidfrastiawan@unida.gontor.ac.id
}

\begin{abstract}
Environment is a very important thing to maintain and preserve. From the perspective of religion or ethics there is has been done. But in the development of human life, it seems that the impact of industrialization begin to cause various enviromental problems. Therefore, regulation that relating to the production in a business and/or activity are needed, one of which is EIA-Environmental Impact Assessment (in Indonesia usually called by Amdal). This study aims to describe the role of EIA for guarding bussiness ethics on the environtment. The method is use qualitative-decriptive-literature. Result from this study is the existence of "Kerangka Acuan," "Andal," and "RKL-RPL" in EIA documents can be an instrument for guarding this ethics, in other side there are contain a "mashlahah" to maintain and preserve the environment.
\end{abstract}

Keywords: Environtment, EIA, Ethics

\section{Pendahuluan}

Industrialisasi muncul sebagai akibat dari perkembangan industri. Tindakan di dalam bisnis cenderung didasarkan atas efisiensi serta terkadang terkesan mengesampingkan aspek akhlak, etika, dan moralitas. Hal inilah yang merupakan titik awal dari perubahan cara pandang manusia terhadap lingkungannya. Pengawasan terhadap industri merupakan suatu hal yang mutlak dan sangat penting untuk dapat mengurangi terjadinya pencemaran lingkungan dan menjaga kelestariannya.

Manusia sebagai khalifah Allah SWT di muka bumi dituntut untuk dapat memakmurkan bumi besrta isinya. Lingkungan (bumi) merupakan amanah bagi manusia, sesuai dengan firman Allah SWT dalam surah al-Baqarah ayat 30:

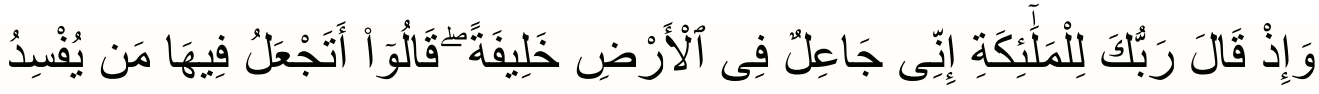

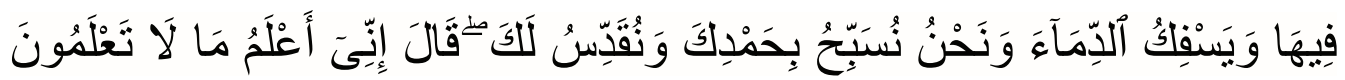


Artinya: "Dan (ingatlah) ketika Tuhanmu berfirman kepada para malaikat, "Aku hendak menjadikan khalifah di bumi." Mereka berkata, "Apakah Engkau hendak menjadikan orang yang merusak dan menumpahkan darah di sana, sedangkan kami bertasbih memuji-Mu dan menyucikan nama-Mu?" Dia berfirman, "Sungguh, Aku mengetahui apa yang tidak kamu ketahui."1

Kontekstualisasi peran khalifah tersebut adalah memelihara lingkungan. ${ }^{2}$ Islam tidak melarang manusia untuk melakukan berbagai kegiatan ekonomi, sepanjang tidak melanggar dari nilai-nilai syariat. Pemanfaatan tersebut hendaknya juga diimbangi dengan menjaga keseimbangan alam serta menghindari segala sesuatu yang dapat menimbulkan kerusakannya. Menjaga lingkungan hidup dapat diartikan pula sebagai wujud di dalam menjalankan perintah Allah SWT.

Di sisi lain, terdapat konsep etika yang merupakan petunjuk bagaimana manusia harus berperilaku dan bertanggung jawab. ${ }^{3}$ Dalam masalah lingkungan, etika selalu berbicara tentang baik dan buruk, pantas dan tidak pantas atas perilaku manusia terhadap lingkungannya. Suatu tindakan bisnis, ketika mengesampingkan aspek kelestarian lingkungan tentu tindakannya tersebut akan dianggap tidak baik dan tidak pantas

Meskipun di dalam agama dan juga etika telah terdapat pembahasan tentang bagaimana seharusnya manusia berperilaku dan bertindak terhadap lingkungannya, namun perlu disadari bahwa ternyata penurunan kualitas lingkungan masih tetap saja meningkat. Oleh karena itu, diperlukan suatu produk hukum yang memuat sanksi atas tindakan dan perilaku (khususnya bisnis) yang dapat mencemari atau merusak lingkungan.

Dari sisi hukum, di dalam Pasal 1 Ayat (11) Undang-Undang No. 32 tahun 2009, Amdal wajib dimiliki oleh setiap usaha dan/atau kegiatan yang berdampak penting terhadap lingkungan. Amdal adalah kajian mengenai dampak penting suatu usaha dan/atau kegiatan yang direncanakan pada lingkungan hidup yang diperlukan bagi proses pengambilan keputusan tentang penyelenggaraan usaha

\footnotetext{
${ }^{1}$ Kementerian Agama RI, Al-Qur'an dan Tafsirnya (Edisi yang Disempurnakan), vol. 1 (Jakarta: Lentera Abadi, 2010), 74.

${ }^{2}$ Kementerian Agama RI, Pelestarian Lingkungan Hidup (Tafsir al-Qur'an Tematik, Edisi yang Disempurnakan) (Jakarta: Lajnah Pentashihan Mushaf al-Qur'an, 2012), 8.

${ }^{3}$ Mohamad Soerjani, Pembangunan dan Lingkungan: Meniti Gagasan dan Pelaksanaan Sustainable Development (Jakarta: Institut Pendidikan dan Pengembangan Lingkungan, 1997), 106-107.
} 
dan/atau kegiatan. Dengan dimasukkannya Amdal ke dalam proses perencanaan suatu usaha dan/atau kegiatan, maka akan diperoleh pandangan yang lebih luas dan mendalam, sehingga dapat diambil keputusan optimal dari berbagai alternatif yang tersedia, serta dapat mempertimbangkan akibat yang mungkin ditimbulkan guna mempersiapkan langkah untuk menanggulangi dampak negatif dan mengembangkan dampak positif yang dimungkinkan terjadi. ${ }^{4}$

Jika masalah lingkungan sangat rentan dari sisi agama maupun etika, maka untuk menjaganya sangatlah diperlukan sebuah ketentuan hukum yang mengikat setiap wajib hukum. Peranan Amdal sangatlah penting untuk mengatur, mengawasi, serta memberikan sanksi hukuman (bagi yang melanggar) dalam hal menjaga dan melestarikan lingkungan sebagai sebuah produk hukum yang diatur dalam peraturan perundang-undangan di Indonesia.

\section{Akhlak Sebagai Basis dari Etika}

\section{Etika dalam Tinjauan Falsafi}

Standar perilaku dan karakter suatu masyarakat dipengaruhi oleh berbagai sumber. ${ }^{5}$ Corak antara masyarakat di suatu daerah dengan daerah yang lain tidaklah sama. Dalam memandang suatu hal misalnya, di suatu daerah tertentu hal tersebut dianggap biasa dan wajar-wajar saja, tetapi mungkin di daerah lain merupakan suatu hal yang dianggap luar biasa atau bahkan menyimpang.

Etika adalah bagian dari filsafat dan merupakan cabang filsafat yang disebut dengan filsafat moral. Filsafat ini berbicara tentang praxis (tindakan) manusia serta mempelajari baik buruknya perilaku manusia. ${ }^{6}$ Sudah sejak lama etika menjadi pembahasan tokoh-tokoh filsafat. Mereka memiliki pandangan masingmasing tentang tujuan dan bagaimana etika tersebut diterapkan.

Tindakan atau perilaku seseorang ditentukan oleh pertimbangan etika dan moral. ${ }^{7}$ Etika memiliki peranan penting dalam membatasi tindakan-tindakan

${ }^{4}$ Mursid Raharjo, Memahami Amdal (Yogyakarta: Graha Ilmu, 2012), 43-44.

${ }^{5}$ Faisal Badroen, dkk., Etika Bisnis dalam Islam, vol. 1 (Jakarta: Kencana Prenada Media Group, 2012), 25.

${ }^{6}$ Yadi Purwanto, Etika Profesi Psikologi Profetik Perspektif Psikologi Islami (Bandung: PT. Refika Aditama, 2007), 42. 16.

${ }^{7}$ Sofyan S. Harahap, Etika Bisnis dalam Perspektif Islam (Jakarta: Salemba Empat, 2011), 
manusia untuk mempertimbangkan apakah tindakannya tersebut baik atau buruk, benar atau salah, berakibat lebih baik atau lebih buruk, pantas atau tidak pantas.

Etika terkait erat dengan agama, yang merupakan sumber nilai dalam menentukan baik dan buruk. ${ }^{8}$ Di satu sisi, etika juga bersumber dari adat kebiasaan suatu tempat. Etika yang bersumber dari agama dibentuk berdasarkan wahyu Tuhan. Dalam perjalanannya, etika diturunkan terus-menerus kepada generasi selanjutnya dan terus berkembang menjadi sebuah standar perilaku yang menciptakan karakter dan corak suatu masyarakat.

Etika dibedakan dalam tiga pengertian pokok, yaitu ilmu tentang apa yang baik dan kewajiban moral, kumpulan asas atau nilai yang berkenaan dengan akhlak, dan nilai mengenai benar dan salah yang dianut suatu golongan atau masyarakat. ${ }^{9}$

Dalam etika, nilai perilaku manusia dapat dibedakan dari dua sudut pandang. ${ }^{10}$ Pertama, teleologis, yaitu baik dan buruknya perilaku manusia ditentukan oleh tujuan perilaku tersebut, jika tujuannya baik maka dianggap baik, namun jika tujuannya buruk maka dianggap buruk. Kedua, deontologis, yaitu baik dan buruknya perilaku manusia ditentukan oleh proses bagaimana suatu perilaku tersebut dilakukan, jika tujuannya baik tetapi cara yang ditempuh salah maka dianggap buruklah perilaku tersebut..

Kekacauan dalam melihat dua hal tersebut mengakibatkan apa yang dimaksud dengan etika menjadi kabur. ${ }^{11}$ Perilaku yang dilakukan manusia akan menimbulkan pandangan yang berbeda dari masing-masing sisi. Namun, berdasarkan dua pandangan tersebut dapat ditarik sebuah garis lurus bahwa suatu perbuatan haruslah memiliki tujuan yang baik dan dilakukan juga dengan proses yang baik, dengan begitu jika ditinjau dari segi teleologis maupun deontologis perilaku tersebut sama-sama dapat dimasukkan dalam kategori yang sama, yaitu perilaku yang baik tanpa menimbulkan pertentangan di antara keduanya.

${ }^{8}$ Ibid., 18.

${ }^{9}$ Muhammad Mufid, Etika dan Filsafat Komunikasi, vol. 1 (Jakarta: Kencana Prenada Media Group, 2012), 173.

${ }^{10}$ Mohammad Muslih, Pengantar Ilmu Filsafat (Ponorogo: Darussalam University Press, 2008), 75.

${ }^{11}$ Ibid. 


\section{Perbandingan Akhlak, Etika, dan Moralitas}

Akhlak diartikan sebagai budi pekerti, perangai, tingkah laku atau tabiat. ${ }^{12}$ Kemudian etika diartikan sebagai sebuah prinsip moral yang mengatur tingkah laku manusia agar senantiasa menuju kepada hal yang baik. ${ }^{13}$ Sedangkan moral diartikan sebagai tindakan manusia yang sesuai dengan ukuran yang diterima oleh umum. ${ }^{14}$

Perbedaan antara akhlak dan etika adalah etika bertitik tolak dari akal pikiran, sedangkan akhlak berdasarkan ajaran dari Allah SWT dan Rasulullah SAW. Perbedaan antara etika dan moral adalah etika lebih banyak bersifat teori dan merupakan tingkah laku manusia secara umum (universal), sedangkan moral lebih banyak bersifat praktis dan bersifat lokal serta lebih khusus. ${ }^{15}$ Menurut Anne T. Lawrence and James Weber, etika dapat memberitahu kita apakah perilaku kita bermoral atau tidak, dan merupakan sebuah panduan untuk perilaku yang bermoral dan sifatnya mendasar. ${ }^{16}$ Dapat dipahami bahwa akhlak dan etika samasama merupakan sebuah standar dalam berperilaku (akhlak bersumber dari wahyu dan etika bersumber dari akal) sedangkan moral adalah tindakan seseorang dalam berperilaku.

Akhlak merupakan basis utama dari etika. Akhlak yang baik yang tumbuh dalam jiwa setiap masing-masing individu tentunya akan membawa dampak yang baik dalam tata perilaku individu tersebut dalam kesehariannya. Akhlak yang diterapkan ini kemudian menjadi kebiasaan dan berubah menjadi sebuah prinsipprinsip dasar berperilaku (etika). Etika ini yang kemudian terus dipertahankan oleh masyarakat sebagai standar moral kehidupan mereka dan terus diturunkan kepada generasi selanjutnya.

\footnotetext{
${ }^{12}$ Buchari Alma, Dasar-Dasar Etika Bisnis Islam (Bandung: CV. Alfabeta, 2003), 53

${ }^{13}$ A.S. Hornby, Oxford Advanced Learner's Dictionary of Current English, vol. 5 (English: Oxford University Press, 1995), 393.

${ }^{14}$ Alma, Dasar-Dasar Etika, 54.

${ }^{15}$ Ibid.

${ }^{16}$ Anne T. Lawrence and James Weber, Business and Society: Stakeholders, Ethics, Public Policy, vol. 14 (New York: McGraw-Hill, 2014), 69.
} 


\section{Sumber-Sumber Etika dalam Islam}

Pertama, al-Qur'an dan al-Hadis. Firman Allah SWT dalam surah al-Ahzab ayat 21:

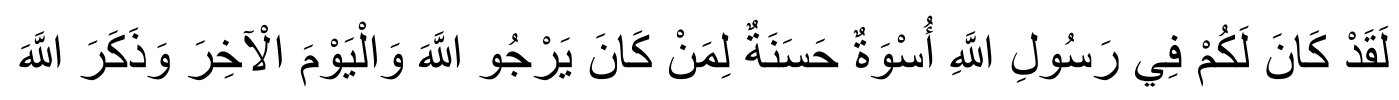

Artinya: "Sungguh, telah ada pada diri (Rasulullah) itu suri teladan yang baik bagimu (yaitu) bagi orang yang mengharap (rahmat) Allah dan (kedatangan) hari kiamat dan yang banyak mengingat Allah". ${ }^{17}$

Sabda Rasulullah SAW:

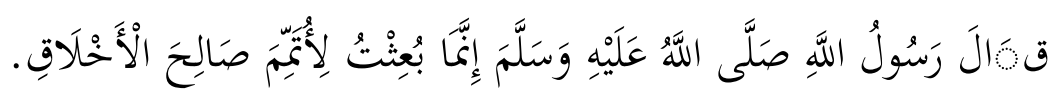

Artinya: "Rasulullah SAW bersabda, sesungguhnya aku diutus hanya untuk menyempurnakan kesalehan akhlak". ${ }^{18}$

Rasulullah SAW diutus ke muka bumi untuk membawa misi memperbaiki dan menyempurnakan akhlak umat manusia dengan landasan wahyu al-Qur'an dan al-Hadis, yang kemudian secara filsafat, etika Islam mendasarkan diri pada agama untuk menilai suatu perilaku manusia. ${ }^{19}$ Etika dalam kehidupan umat Islam adalah hal yang sangat mendasar dan penting sebagai implikasi dari akhlak seseorang. Hal ini sangat diperlukan oleh umat manusia untuk menentukan sikap dan perilakunya di dalam kehidupannya.

Kedua, qiyas. Firman Allah SWT dalam surat an-Nisa' ayat 19:

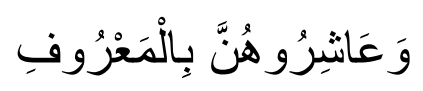

Artinya: "Dan bergaullah dengan mereka menurut cara yang patut". ${ }^{20}$

Di dalam ayat tersebut ma'ruf diartikan "yang patut", yaitu pergaulan yang diakui baik dan patut oleh masyarakat umum. ${ }^{21}$ Tafsir dari ayat ini jika di-qiyas-

\footnotetext{
${ }^{17}$ Kementerian Agama RI, Al-Qur'an dan Tafsirnya (Edisi yang Disempurnakan), vol. 7 (Jakarta: Lentera Abadi, 2010), 638-639.

${ }^{18}$ Software Maktabah Syameela, Kitab Musnad Ahmad: Bab Musnad Abu Hurairah RA, Juz 18, Nomor 137 (Maret 2018).

${ }^{19}$ Muhaimin, Perbandingan Praktik Etika Bisnis Etnik Cina dan Pembisnis Lokal (Yogyakarta: Pustaka Pelajar, 2011), 33.

${ }^{20}$ Kementerian Agama RI, Al-Qur'an dan Tafsirnya (Edisi yang Disempurnakan), vol. 2 (Jakarta: Lentera Abadi, 2010), 133.

${ }^{21}$ Hamka, Tafsir al-Azhar, vol. 4 (Jakarta: PT. Pustaka Panjimas, 1983), 300.
} 
kan maka akan merujuk kepada etika, karena memiliki kesamaan berupa tuntunan untuk berperilaku yang baik dan sesuai dengan kebiasaan di suatu daerah.

Ketiga, 'urf. 'Urf cenderung diartikan sebagai adat kebiasaan. ${ }^{22}$ Menurut kesepakatan jumhur ulama, suatu adat atau 'urf dapat diterima, jika tidak bertentangan dengan syariat, tidak menyebabkan ke-mafsadat-an dan menghilangkan ke-mashlahat-an, telah berlaku pada umumnya orang Muslim, tidak berlaku dalam ibadah mahdhah, dan 'urf tersebut sudah memasyarakat.. ${ }^{23}$ Ketentuan kebiasaan (batasan, penerapan, atau ukurannya) ditentukan oleh daerah tempat diberlakukannya 'urf tersebut.

\section{Peran Amdal dalam Mengawal Etika Bisnis Terhadap Lingkungan}

Amdal disusun oleh pemrakarsa pada tahap perencanaan suatu usaha dan/atau kegiatan. Penyusunan Amdal dituangkan ke dalam dokumen Amdal yang terdiri atas Kerangka Acuan; Andal; dan RKL-RPL. ${ }^{24}$ Menurut Peraturan Menteri Lingkungan Hidup No. 08 tahun 2006, penjelasan tentang dokumen Amdal tersebut adalah sebagai berikut:

\section{KA-Andal}

Kerangka Acuan Analisis Dampak Lingkungan Hidup (KA-Andal) adalah ruang lingkup studi analisis dampak lingkungan hidup yang merupakan hasil pelingkupan yang disepakati oleh Pemrakarsa/Penyusun Amdal dan Komisi Penilai Amdal. Analisis Dampak Lingkungan Hidup (Andal) adalah telaahan secara cermat dan mendalam tentang dampak penting suatu rencana usaha dan/atau kegiatan. Pedoman penyusunan KA-Andal digunakan sebagai dasar bagi penyusunan KA-Andal baik KA-Andal kegiatan tunggal, KA-Andal kegiatan terpadu/multisektor maupun KA-Andal kegiatan dalam kawasan.

Tujuan penyusunan KA-Andal adalah merumuskan lingkup dan kedalaman studi Andal; mengarahkan studi Andal agar berjalan secara efektif dan efisien sesuai dengan biaya, tenaga, dan waktu yang tersedia. Fungsi dokumen KA-Andal adalah sebagai rujukan penting bagi pemrakarsa, instansi yang membidangi

\footnotetext{
${ }^{22}$ Imam Musbikin, Qawa 'id al-Fiqhiyah, vol. 1 (Jakarta: PT. RajaGrafindo Persada, 2001), 93.

${ }^{23}$ Hasbiyallah, Fiqh dan Ushul Fiqh: Metode Istinbath dan Istidlal (Bandung: PT. Remaja Rosdakarya, 2014), 137.

${ }^{24}$ Mursid Raharjo, Memahami Amdal, 43-44.
} 
rencana usaha dan/atau kegiatan, dan penyusun studi Amdal tentang lingkup dan kedalaman studi Andal yang akan dilakukan; sebagai salah satu bahan rujukan bagi penilai dokumen Andal untuk mengevaluasi hasil studi Andal. Dokumen KA-Andal harus mencerminkan secara jelas dan tegas wawasan lingkungan hidup yang harus dipertimbangkan dalam pembangunan suatu rencana usaha dan/atau kegiatan.

\section{Rencana Pengelolaan Lingkungan Hidup (RKL)}

Rencana Pengelolaan Lingkungan Hidup (RKL) adalah upaya penanganan dampak penting terhadap lingkungan hidup yang ditimbulkan akibat dari rencana usaha dan/atau kegiatan. Dokumen RKL merupakan dokumen yang memuat upaya-upaya mencegah, mengendalikan dan menanggulangi dampak penting lingkungan hidup yang bersifat negatif dan meningkatkan dampak positif yang timbul sebagai akibat dari suatu rencana usaha dan/atau kegiatan.

Mengingat dokumen Amdal merupakan bagian dari studi kelayakan, maka dokumen RKL hanya akan bersifat memberikan pokok-pokok arahan, prinsipprinsip, kriteria atau persyaratan untuk pencegahan/penanggulangan/pengendalian dampak. Rencana pengelolaan lingkungan hidup dapat berupa pencegahan dan penanggulangan dampak negatif, serta peningkatan dampak positif yang bersifat strategis. Rencana pengelolaan lingkungan hidup harus diuraikan secara jelas, sistimatis, serta mengandung 4 ciri-ciri pokok. Untuk menangani dampak penting yang sudah diprediksi dari studi Andal, dapat menggunakan salah satu atau beberapa pendekatan lingkungan hidup yang selama ini dikenal seperti: teknologi, sosial ekonomi, maupun institusi. Mengingat dokumen RKL disusun sekaligus dengan dokumen Andal dan RPL, dan ketiganya dinilai sekaligus maka format dokumen RKL langsung berorientasi pada keempat pokok rencana pengelolaan lingkungan hidup.

\section{Rencana Pemantauan Lingkungan Hidup (RPL)}

Rencana Pemantauan Lingkungan Hidup (RPL) adalah upaya pemantauan komponen lingkungan hidup yang terkena dampak penting akibat dari rencana usaha dan/atau kegiatan. Pemantauan lingkungan hidup dapat digunakan untuk memahami fenomena-fenomena yang terjadi pada berbagai tingkatan, mulai dari tingkat proyek (untuk memahami perilaku dampak yang timbul akibat usaha 
dan/atau kegiatan), sampai ke tingkat kawasan atau bahkan regional; tergantung pada skala masalah yang dihadapi. Pemantauan merupakan kegiatan yang berlangsung secara terus-menerus, sistematis dan terencana. Pemantauan dilakukan terhadap komponen lingkungan yang relevan untuk digunakan sebagai indikator untuk mengevaluasi penaatan (compliance), kecenderungan (trendline), dan tingkat kritis (critical level) dari suatu pengelolaan lingkungan hidup.

Ada beberapa faktor yang perlu diperhatikan dalam penyusunan dokumen rencana pemantauan lingkungan hidup. Pertama, komponen/parameter lingkungan hidup yang dipantau hanyalah yang mengalami perubahan mendasar atau terkena dampak penting. Kedua, aspek-aspek yang dipantau perlu memperhatikan benar dampak penting yang dinyatakan dalam Andal dan sifat pengelolaan dampak lingkungan hidup yang dirumuskan dalam dokumen RKL. Ketiga, pemantauan dapat dilakukan pada sumber penyebab dampak dan/atau terhadap komponen/parameter lingkungan hidup yang terkena dampak. Dengan memantau kedua hal tersebut sekaligus akan dapat dinilai/diuji efektivitas kegiatan pengelolaan lingkungan hidup yang dijalankan. Keempat, pemantauan lingkungan hidup harus layak secara ekonomi. Walaupun aspek-aspek yang akan dipantau telah dibatasi pada hal-hal yang penting saja (seperti diuraikan dalam faktor pertama sampai ketiga), namun biaya yang dikeluarkan untuk pemantauan perlu diperhatikan mengingat kegiatan pemantauan senantiasa berlangsung sepanjang usia usaha dan/atau kegiatan. Kelima, rancangan pengumpulan dan analisis data aspek-aspek yang perlu dipantau, mencakup jenis data yang dikumpulkan; lokasi pemantauan; frekuensi dan jangka waktu pemantauan; metode pengumpulan data (termasuk peralatan dan instrumen yang digunakan untuk pengumpulan data); metode analisis data. Keenam, dokumen RPL perlu memuat tentang kelembagaan pemantauan lingkungan hidup. Kelembagaan pemantauan lingkungan hidup yang dimaksud di sini adalah institusi yang bertanggungjawab sebagai penyandang dana pemantauan, pelaksana pemantauan, pengguna hasil pemantauan, dan pengawas kegiatan pemantauan.

Ekonomi syariah adalah pengetahuan bagaimana menggali dan mengimplementasi sumber daya material untuk memenuhi kebutuhan dan kesejahteraan manusia, di mana penggalian itu harus sesuai dengan syariat Islam. 
Ekonomi syariah juga didefinisikan sebagai tata aturan yang berkaitan dengan cara berproduksi, distribusi, dan konsumsi serta kegiatan lain yang sesuai dengan al-Qur'an dan al-Hadis. ${ }^{25}$

Allah SWT telah melimpahkan berbagai nikmat kepada manusia. Segala yang diciptakan di langit dan bumi adalah untuk dimanfaatkan oleh manusia guna memenuhi kebutuhannya. Firman Allah SWT dalam surat Ibrahim ayat 32-34:

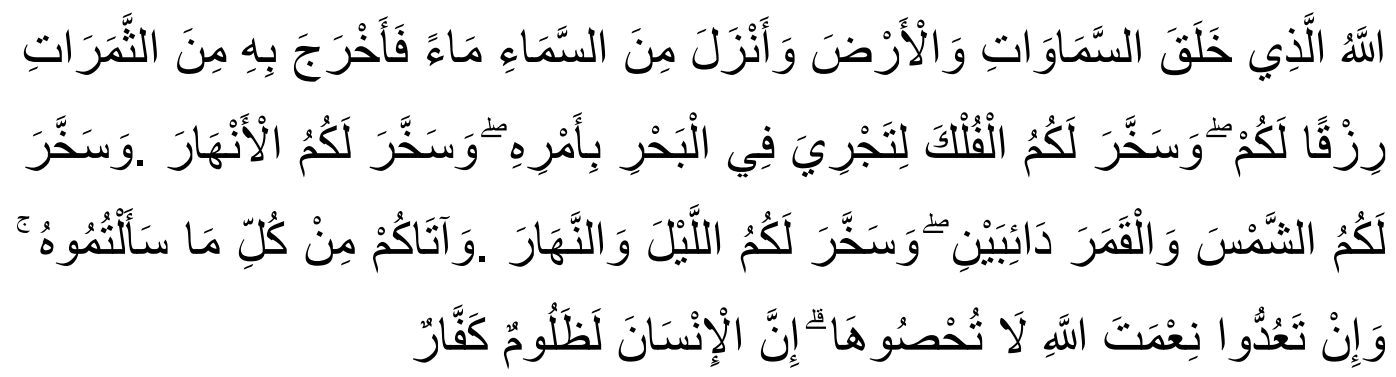

Artinya: "Allah-lah yang telah menciptakan langit dan bumi dan menurunkan air (hujan) dari langit, kemudian dengan (air hujan) itu Dia mengeluarkan berbagai buah-buahan sebagai rezeki untukmu; dan Dia telah menundukkan kapal bagimu agar berlayar di lautan dengan kehendak-Nya, dan Dia telah menundukkan sungai-sungai bagimu. Dan dia telah menundukkan matahari dan bulan bagimu yang terus-menerus beredar (dalam orbitnya); dan telah menundukkan malam dan siang bagimu. Dan Dia telah memberikan kepadamu segala apa yang kamu mohonkan kepada-Nya. Dan jika kamu menghitung nikmat Allah, niscaya kamu tidak akan mampu menghitungnya. Sungguh, manusia itu sangat zalim dan sangat mengingkari (nikmat Allah)'”. ${ }^{26}$

Dalam produksi, etika yang terpenting adalah menjaga sumber daya alam dari kerusakan sebagai salah satu cara mensyukuri nikmat dari Allah SWT ${ }^{27}$. Etika harus dibangun dan dilandasi oleh prinsip-prinsipnya. Prinsip-prinsip tersebut adalah kesatuan (unity), keseimbangan/keadilan (equilibrium), kehendak bebas/ikhtiar (free will), pertanggungjawaban (responsibility) dan kebenaran (truth), serta kebajikan (wisdom) dan kejujuran (fair). ${ }^{28}$ Di dalam bisnis terkadang dihadapkan pada keterbatasan dalam mengawasi kemampuan teknologi, selain itu tantantangan-tantangan besar dalam bisnis seringkali menimbulkan moral hazard

\footnotetext{
${ }^{25}$ Abdul Aziz, Ekonomi Islam: Analisis Mikro \& Makro (Yogyakarta: Graha Ilmu, 2008), 1 4.

${ }^{26}$ Kementerian Agama RI, Al-Qur'an dan Tafsirnya (Edisi yang Disempurnakan), vol. 5 (Jakarta: Lentera Abadi, 2010), 154.

${ }^{27}$ Yusuf Qardhawi, Norma dan Etika Ekonomi Islam, ter. Zainal Arifin (Jakarta: Gema Insani Press, 1997), 119.

${ }^{28}$ Saiful Anwar, dkk., Pengantar Falsafah Ekonomi dan Keuangan Syariah, vol. 1 (Depok: Rajawali Pers, 2018), 106.
} 
terhadap lingkungan. Untuk itu diperlukanlah suatu pedoman atau regulasi yang dapat meminimalisir kemungkinan buruk tersebut guna menjaga tanggungjawab etis dari suatu bisnis.

Amdal atau Analisis Mengenai Dampak Lingkungan (Environmental Impact Assessment) merupakan kajian mengenai kemungkinan dampak besar dan penting suatu rencana dan/atau kegiatan terhadap lingkungan hidup. ${ }^{29}$ Peraturan Pemerintah Republik Indonesia Nomor 27 Tahun 2012 Tentang Izin Lingkungan mengamanatkan, "Penyusunan Amdal dituangkan ke dalam dokumen Amdal yang terdiri atas Kerangka Acuan, Andal, RKL-RPL” (Pasal 5 Ayat (1) PP RI No. 27 Tahun 2012). Unsur-unsur tersebut pada dasarnya bertujuan untuk menjaga etika suatu usaha dan/atau kegiatan terhadap lingkungan hidup. Dalam menyusun dokumen Amdal, pemrakarsa wajib menggunakan pendekatan studi tunggal, terpadu, atau kawasan (mencakup perencanaan, pengelolaan, serta pembinaan dan pengawasan). Penyusunan dokumen Amdal juga mengikutsertakan masyarakat yang terkena dampak, pemerhati lingkungan hidup, dan/atau yang terpengaruh atas segala keputusan dalam proses Amdal. Hal ini penting dilakukan karena daerah di sekitar usaha dan/atau kegiatan adalah yang paling dekat terkena dampak, karena suatu usaha dan/atau kegiatan memiliki tanggung jawab yang besar terhadap lingkungan hidup dan sosial masyarakat di sekitarnya. Penyusun Amdal wajib memiliki sertifikat kompetensi, agar dokumen Amdal yang dihasilkan benar-benar telah disusun sesuai dengan tata administrasi dan prosedur yang berlaku serta dapat dipertanggung jawabkan.

Dalam aktivitasnya, suatu usaha dan/atau kegiatan harus memperhitungkan berbagai akibat yang dapat ditimbulkan oleh keputusan maupun tindakannya. ${ }^{30}$ Tanggung jawab sosial merupakan pelaksanaan etika di dalamnya. Pelaksanaan etik ini termasuk masalah produksi barang dan jasa dan penjagaan kelestarian lingkungan dari ancaman berbagai pencemaran dengan batas-batas wajar yang tidak melanggar peraturan pemerintah. ${ }^{31}$ Selain itu, dampak yang mungkin

\footnotetext{
${ }^{29}$ Cecep Dani Sucipto dan Asmadi, Aspek Kesehatan Masyarakat dalam Amdal (Yogyakarta: Gosyen Publishing, 2011), 3.

${ }^{30}$ Ismail Solihin, Pengantar Bisnis: Pengenalan Praktis \& Studi Kasus, vol. 1 (Jakarta: Kencana, 2006), 101-105.

${ }^{31}$ Buchari Alma dan Donni Juni Priansa, Manajemen Bisnis Syariah: Menanamkan Nilai dan Praktik Syariah dalam Bisnis Kontemporer (Bandung: Alfabeta, 2014), 420.
} 
ditimbulkan juga harus diperkirakan. Jangan sampai ketika terjadi suatu dampak, solusi atas dampak tersebut belum terpikirkan. Hal ini terwujud dalam KA-Andal, RKL, dan RPL.

Berdasarkan penjelasan-penjelasan pada sub bab sebelumnya, diketahui bahwa KA-Andal merupakan hasil pelingkupan (telaahan secara cermat dan mendalam tentang dampak penting suatu rencana usaha dan/atau kegiatan) yang disepakati oleh pemrakarsa/penyusun Amdal dan Komisi Penilai Amdal. KAAndal ini merupakan dokumen penting yang memberikan rujukan tentang kedalaman studi Andal yang akan dicapai serta mencerminkan secara jelas dan tegas wawasan lingkungan hidup yang harus dipertimbangkan dalam pembangunan suatu rencana usaha dan/atau kegiatan. Semakin baik hasil pelingkupan maka semakin tegas dan jelas arah dari studi Andal yang dilakukan.

Selanjutnya, dokumen RKL merupakan dokumen yang memuat upayaupaya mencegah, mengendalikan, dan menanggulangi dampak penting lingkungan hidup yang timbul sebagai akibat dari suatu rencana usaha dan/atau kegiatan. Sifatnya adalah sebatas memberikan pokok-pokok arahan, prinsipprinsip, kriteria atau persyaratan untuk pencegahan/penanggulangan/pengendalian dampak. Adanya RKL ini setidaknya dapat memberikan penanganan yang cepat ketika terjadi suatu dampak, sehingga dapat berjalan dengan terarah dan tepat.

Sedangkan RPL digunakan untuk memahami fenomena-fenomena yang terjadi pada berbagai tingkatan (proyek, kawasan, atau regional). Pemantauan merupakan kegiatan yang berlangsung secara terus menerus, sistematis, dan terencana. Pemantauan bertujuan untuk mengetahui sedini mungkin dampak yang mungkin muncul sebelum meluas dan menjadi sulit untuk ditanggulangi. Dengan adanya pemantauan, diharapkan suatu usaha dan/atau kegiatan dapat berjalan sesuai dengan peraturan yang berlaku serta berwawasan lingkungan.

Meniadakan hubungan ekonomi dari nilai-nilai etika adalah sesuatu kekeliruan besar dan tidak bertanggungjawab atas keselamatan manusia dan alam semesta. $^{32}$ Peraturan perundang-undangan tentang lingkungan hidup yang terintegrasikan dengan etika akan efektif dalam menekan kemungkinan-

${ }^{32}$ Nashruddin Baidan dan Erwati Aziz, Etika Islam dalam Berbisnis (Yogyakarta: Pustaka Pelajar, 2014), 161-162. 
kemungkinan dalam pencemaran dan perusakan lingkungan. Oleh karena itu, posisi Amdal mtlak dibutuhkan sebagai bagian dari usaha untuk menjaga kemaslahatan terhadap lingkungan.

Etika pada dasarnya adalah menaati hukum. Dalam ekonomi syariah, landasan etika setidaknya ada 4, yaitu shiddiq, amanah, tabligh, dan fathanah, nilai-nilai etika yang mendasari inilah yang harus dijaga. ${ }^{33}$ Adanya Kerangka Acuan, Andal, dan RKL-RPL di dalam dokumen Amdal setidaknya dapat menjadi instrumen dalam menjaga nilai-nilai etika tersebut. Oleh karena itu, pada satu sisi Amdal memiliki peranan yang sangat penting dalam menjaga nilai-nilai etika bisnis dari suatu usaha dan/atau kegiatan agar tetap berjalan etis dengan lingkungan hidup sesuai dengan prinsip-prinsip etika.

\section{Kesimpulan}

Menjaga dan melestarikan lingkungan merupakan salah satu tujuan yang terdapat di dalam agama maupun etika. Meskipun demikian, terkadang di dalam dunia bisnis cenderung mengabaikan hal-hal tersebut. Dengan adanya Amdal, setidaknya perilaku-perilaku dalam suatu usaha dan/atau kegiatan yang akan menjurus kepada perusakan lingkungan dapat diminimalisir. Dokumen KA-Andal bertujuan untuk memberikan telaahan secara cermat dan mendalam tentang dampak penting suatu rencana usaha dan/atau kegiatan. Dokumen RKL bertujuan untuk memuat upaya-upaya mencegah, mengendalikan dan menanggulangi dampak penting lingkungan hidup yang bersifat negatif dan meningkatkan dampak positif yang timbul sebagai akibat dari suatu rencana usaha dan/atau kegiatan. Dokumen RPL memuat tentang upaya pemantauan komponen lingkungan hidup yang terkena dampak penting akibat dari rencana usaha dan/atau kegiatan. Pemantauan merupakan kegiatan yang berlangsung secara terus-menerus, sistematis dan terencana. Dokumen Amdal yang meliputi KAAndal, RKL, dan RPL merupakan instrumen-instrumen penting di dalam Amdal dalam upaya menjaga dan melestarikan demi kemaslahatan lingkungan hidup.

${ }^{33}$ Veithzal Rivai, dkk., Islamic Business and Economic Ethics: Mengacu pada al-Qur'an dan Mengikuti Jejak Rasulullah SAW dalam Bisnis, Keuangan, dan Ekonomi (Jakarta: Bumi Aksara, 2012), 9. 


\section{Daftar Pustaka}

Alma, Buchari, dan Donni Juni Priansa. Manajemen Bisnis Syariah: Menanamkan Nilai dan Praktik Syariah dalam Bisnis Kontemporer. Bandung: Alfabeta, 2014.

Alma, Buchari. Dasar-Dasar Etika Bisnis Islam. Bandung: CV. Alfabeta, 2003.

Anwar, Saiful, dkk. Pengantar Falsafah Ekonomi dan Keuangan Syariah. Vol. 1. Depok: Rajawali Pers, 2018.

Aziz, Abdul. Ekonomi Islam: Analisis Mikro \& Makro. Yogyakarta: Graha Ilmu, 2008.

Badroen, Faisal, dkk. Etika Bisnis dalam Islam. Vol. 1. Jakarta: Kencana Prenada Media Group, 2012.

Baidan, Nashruddin, dan Erwati Aziz. Etika Islam dalam Berbisnis. Yogyakarta: Pustaka Pelajar, 2014.

Hamka. Tafsir al-Azhar. Vol. 4. Jakarta: PT. Pustaka Panjimas, 1983.

Harahap, Sofyan S. Etika Bisnis dalam Perspektif Islam. Jakarta: Salemba Empat, 2011.

Hasbiyallah. Fiqh dan Ushul Fiqh: Metode Istinbath dan Istidlal. Bandung: PT. Remaja Rosdakarya, 2014.

Hornby, A.S. Oxford Advanced Learner's Dictionary of Current English. Vol. 5 English: Oxford University Press, 1995.

Kementerian Agama RI, Al-Qur'an dan Tafsirnya (Edisi yang Disempurnakan). Vol. 1. Jakarta: Lentera Abadi, 2010.

-. Al-Qur'an dan Tafsirnya (Edisi yang Disempurnakan). Vol. 2. Jakarta: Lentera Abadi, 2010.

-. Al-Qur'an dan Tafsirnya (Edisi yang Disempurnakan). Vol. 5. Jakarta: Lentera Abadi, 2010.

-. Al-Qur'an dan Tafsirnya (Edisi yang Disempurnakan). Vol. 7. Jakarta: Lentera Abadi, 2010.

--------. Pelestarian Lingkungan Hidup (Tafsir al-Qur'an Tematik, Edisi yang Disempurnakan. Jakarta: Lajnah Pentashihan Mushaf al-Qur'an, 2012.

Lawrence, Anne T., and James Weber. Business and Society: Stakeholders, Ethics, Public Policy, Vol. 14. New York: McGraw-Hill, 2014.

Mufid, Muhammad. Etika dan Filsafat Komunikasi. Vol. 1. Jakarta: Kencana Prenada Media Group, 2012.

Muhaimin. Perbandingan Praktik Etika Bisnis Etnik Cina dan Pembisnis Lokal. Yogyakarta: Pustaka Pelajar, 2011.

Musbikin, Imam. Qawa'id al-Fiqhiyah. Vol. 1. Jakarta: PT. RajaGrafindo Persada, 2001. 
Muslih, Mohammad. Pengantar Ilmu Filsafat. Ponorogo: Darussalam University Press, 2008.

Peraturan Menteri Lingkungan Hidup No. 08 Tahun 2006.

Purwanto, Yadi. Etika Profesi Psikologi Profetik Perspektif Psikologi Islami. Bandung: PT. Refika Aditama, 2007.

Qardhawi, Yusuf. Norma dan Etika Ekonomi Islam. Terj. Zainal Arifin. Jakarta: Gema Insani Press, 1997.

Raharjo, Mursid. Memahami Amdal. Yogyakarta: Graha Ilmu, 2012.

Rivai, Veithzal. dkk. Islamic Business and Economic Ethics: Mengacu pada alQur'an dan Mengikuti Jejak Rasulullah SAW dalam Bisnis, Keuangan, dan Ekonomi. Jakarta: Bumi Aksara, 2012.

Soerjani, Mohamad. Pembangunan dan Lingkungan: Meniti Gagasan dan Pelaksanaan Sustainable Development. Jakarta: Institut Pendidikan dan Pengembangan Lingkungan, 1997.

Software Maktabah Syameela. Kitab Musnad Ahmad: Bab Musnad Abu Hurairah RA, Juz 18, Nomor 137 (Maret 2018).

Solihin, Ismail. Pengantar Bisnis: Pengenalan Praktis \& Studi Kasus. Vol. 1. Jakarta: Kencana, 2006.

Sucipto, Cecep Dani, dan Asmadi. Aspek Kesehatan Masyarakat dalam Amdal. Yogyakarta: Gosyen Publishing, 2011. 